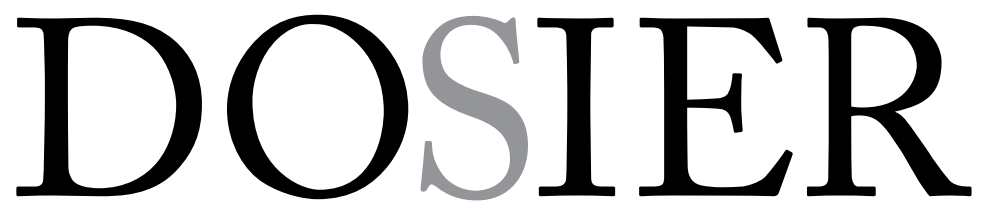

\title{
Versiones \\ del Quijote
}

COORDINACIÓN

JUAN FRANCISCO FERRÉ

PETER BUSH 
VERSIONES DEL QUIJOTE

Juan Francisco Ferré

10
El Quijote es mucho más que una obra literaria. Con el paso de los siglos, la genial novela de Cervantes se ha transformado en una realidad autónoma, un mundo autárquico segregado por los mundos de palabras de sus páginas en otros medios, formatos y soportes, con otros fines, realizando acaso el propósito original de su autor, que no podía ser otro que contaminar la realidad con ficciones alternativas al orden opresivo de lo real.

Desde el principio, El Quijote reclamaba esa transmigración mediática como forma de renovar su lectura, como exigía Borges, gran lector crítico y creativo del texto cervantino en la modernidad, desplazándolo de contexto.

Esta posibilidad de multiplicarse ya estaba inscrita en los planteamientos genuinos de la novela. Recordemos, en este sentido, que Cervantes es, además del cronista cómico de un tiempo histórico extenuado, el primer escritor plenamente consciente de la singularidad específica de las formas narrativas y que el Quijote es el gran experimento novelístico de la literatura universal, un sofisticado artefacto de ficción tan innovador como la imprenta misma.

Este artilugio inventado por Gutenberg, precisamente, la tecnología más revolucionaria de su tiempo, la máquina que con su aparición puso fin a la Edad Media y abrió de par en par las compuertas de la edad moderna, la era crítica que se somete en permanencia a revisión, es el que convierte al Quijote en libro capital, gracias al inmenso beneficio creativo que Cervantes supo extraer de su incorporación a los dispositivos y mecanismos de la ficción literaria.
En la portentosa Segunda parte del Quijote (I6I5) es donde Cervantes afronta ya, por primera vez en la historia de las formas narrativas, el tema de la reproducción, en el mismo sentido en que muchos siglos después lo entendería un pensador de tanto peso como Walter Benjamin, al explorar en la narración las secuelas del poder de la imprenta para desacralizar la literatura como arte y trastornar las categorías de vida y pensamiento de los personajes y la trama en curso. Al convertir la imprenta en un artefacto generador de ficciones y metaficciones, Cervantes pone en marcha una fuente seminal de aproximación a su obra a través de la renovación de los formatos y soportes tecnológicos de cada época.

De ese modo, se han multiplicado a lo largo del último siglo, el siglo de avance tecnológico más vertiginoso de la historia, las versiones del Quijote no solo en otras lenguas, como es obvio desde su aparición, o en la suya propia, asunto más espinoso que habrá de quedar para otro momento, sino en nuevos lenguajes inimaginables para Cervantes y muchos de sus comentaristas tradicionales. El cine, la televisión, los videojuegos, los dibujos animados autóctonos, el cómic, el manga y el anime japoneses, etc. Todos estos medios, formatos y géneros, con estilos y recursos propios, se han apropiado de las ficciones y artificios del Quijote para ofrecerles una oportunidad de actualización mediática. Y se han atrevido, a menudo, a extrapolar sus contenidos para alcanzar nuevas visiones del mundo y de la cultura de los humanos derivadas de sus propias características como medios, jugando con la misma audacia artística con que lo hiciera su "primer autor» en un tiempo antiguo que parecía propicio a todos los experimentos e innovaciones.

No conviene olvidar nunca, para entender con mayor nitidez la condición hipermediática 
del Quijote, que esta novela fundacional del canon literario de la modernidad transnacional encierra entre sus páginas una hilarante reivindicación del juego literario, pero no es un juego en absoluto, o no sólo, aunque altere por completo las reglas del juego de escribir novelas. $E l$ Quijote invita a sus lectores a mantenerse activos y lúcidos durante la lectura y a participar con humor en su aventura ficticia para enseñarles a burlarse de los códigos de conducta a los que se someten constantemente en sus vidas, sin poder librarse de ellos, por más que intenten descodificarlos todo el tiempo.

Es por esta razón por lo que se podría considerar a esta novela de novelas (o meganovela, la primera de la historia, o megaficción) como el más completo y complejo juego de «rol» imaginable sobre las vertiginosas mutaciones y transmutaciones de la identidad de un individuo y la realidad de su entorno. Pues la gran propuesta filosófico-narrativa del Quijote consiste en mostrar cómo los sistemas de creencias y valores producidos por los seres humanos a lo largo de la historia se originan al borde de la nada, en ese margen borroso, esa zona residual de la cognición existente entre el último resplandor de la conciencia intelectiva y la contundente materialidad de objetos y cuerpos.

Como se verá en los textos recogidos en este amplio dosier, El Quijote padece mutaciones en otros medios y lenguajes, siempre con pantallas intermediarias y con interferencias específicas, tanto para reiterarse enfáticamente, mirándose de frente y de perfil en el espejo recreativo de la tecnología a fin de reconocer o no su problemática contemporaneidad, como para diferenciarse libremente como copia creativa de la obra original, produciendo nuevas figuras y apariencias, simulacros innovadores de gran originalidad estética y narrativa, a partir de sus iconos, rasgos y estereotipos más conocidos.
Por todo ello nada mejor que comenzar, como hace el artículo de María José Rodríguez Mosquera ( $E$ El Quijote en imágenes: Adaptaciones cinematográficas y televisivas»), por la recepción creativa del Quijote por parte de los dos medios artísticos y comunicativos (el cine y la televisión) que revolucionaron la cultura del siglo $\mathrm{xx}$ al transformarla en cultura audiovisual de consumo masivo. Es extensa la revisión que Rodríguez Mosquera realiza de la abundante filmografía europea y española que toma al Quijote como pretexto para, variando las modalidades de representación elegidas, con mayor o menor comicidad o acierto, apropiarse del espíritu singular de la obra de Cervantes. Como señala la autora: «Más de un siglo después de que el cine, y posteriormente la televisión, empezaran a aunar texto narrativo e imagen, el personaje y la obra cervantina siguen siendo, como hemos visto, una fuente inagotable de interpretaciones y creaciones». Constituye un dato relevante del interesante estudio de Rodríguez Mosquera, sin embargo, el hecho de que hayan sido diversas cinematografías europeas, siguiendo los proyectos creativos de sus respectivos directores, las que se hayan ocupado de estas adaptaciones, más bien de índole minoritaria o artística, mientras la cinematografía hollywoodiense, la más popular y mayoritaria, permanecía indiferente ante las posibilidades de la obra cervantina, tan popular entre los lectores de su época. Y eso a pesar de la gran influencia y peso paradójico del Quijote en el ámbito literario y académico anglosajón desde el siglo XVIII hasta hoy mismo.

Inscribir El Quijote en la cultura de masas es, de nuevo, lo que supone su asunción en las categorías gráficas y expresivas del manga japonés, como analiza con absoluta pertinencia Clara Monzó en su artículo «Don Quijote en el manga: traducción, transformación y adap- 
tación en la cultura de masas japonesa». En el proceso descrito en este texto por su autora, El Quijote habría sido en un primer momento digerido como referente por la cultura japonesa, a través de la literatura y de las imágenes estereotipadas derivadas de esta, antes de que un género popular de tanto alcance como el manga pudiera a su vez transfigurar la «mitología» quijotesca, en el sentido que daba Roland Barthes a esta expresión ligándola a la cultura de la publicidad, la explotación comercial y los medios estandarizados, en carne de historieta nipona, materia idónea para el manga y su peculiar diseño visual y estilo narrativo con el fin de ofrecerlo al consumo global de masas, incluida la circulación por internet, en un curioso viaje de ida y vuelta entre países y culturas (artes o literaturas) de distintas épocas. En palabras de la autora, glosando la relevancia de esta transferencia cultural: «Imagen y palabra, su incursión en el género del manga contribuye doblemente a la consolidación de su figura como representante del canon literario español y a la difusión de su mito entre los lectores consumidores de la cultura de masas».

El aspecto más avanzado y original de las remediaciones quijotescas, aunque sea como puro pretexto, señuelo comercial o marca de prestigio cultural, reside en su incorporación al mundo tecnológico y lúdico de los videojuegos, como analizan con rigor Miriam Borham y Daniel Escandell en su artículo "Quijobytes: reflejos especulares del mito quijotesco en el ocio electrónico». De todos los nuevos medios de la era digital, el videojuego es el que mejor podría asumir las originales postulados de Cervantes sobre lo real y lo virtual en la mente de los personajes y los lectores, categorizados ahora como gamers, jugones o jugadores de un dominio redefinido por los límites de la tecnología. $\mathrm{El}$ parentesco cognitivo entre la grandiosa farsa

cervantina y estos juegos o «videojuegos» es revelador. El territorio de La Mancha, como la vida cotidiana capitalista, representa en El Quijote el grado cero de la aventura entendida como expansión afectiva de las posibilidades vitales. Es ahí, por tanto, en ese territorio desertizado de lo real en el que se desenvuelve el caótico personaje cervantino, o la lúdica subjetividad posmoderna, donde se origina necesariamente el «ruido de fondo» de lo virtual y lo espectacular que amenaza con totalizar la esfera social contemporánea. La iconografía del Quijote, remediada antes por el cine, la televisión, los dibujos animados o el cómic, se vuelve más contemporánea al introducirse en el diseño de los videojuegos y sus especulativas posibilidades de multiplicar el sentido final de sus aventuras narrativas en una pantalla en ${ }_{3} \mathrm{D}$. Por tanto, como concluyen los autores del artículo, «lo que estas obras hacen es apelar a los elementos que conforman la percepción de don Quijote que ha quedado marcado en el contexto cultural colectivo, empleando un conocimiento superficial de la novela original pero suficiente para que sea reconocible por un público no necesariamente lector de Cervantes».

Profundizando en las versiones cinéfilas del Quijote, el artículo de Bernardo Sánchez («Film ininflamable, o le roman vague») realiza una sugestiva maniobra crítica al contextualizar la obra maestra cervantina en un período y una estética de estilo tan intransferible como la nouvelle vague francesa de los años cincuenta y sesenta, influenciada hasta cierto punto por la adaptación de G. W. Pabst y movida por el mismo impulso romántico de Orson Welles. Con la metáfora de la pira ígnea, la combustión del libro (o la biblioteca) y del celuloide del film, como ya prefigurara Giorgio Agamben en una lectura más filosófica de una secuencia de alto simbolismo de la inconclusa película de 
Welles, Sánchez retoma como focos centrales de su incendiario análisis la cinta Farenheit 45I, gran homenaje a la literatura de ese lector bulímico y amateur empedernido que fue el cineasta François Truffaut, y el cine quijotesco de Jacques Rivette, realizado a todo trance contra las posibilidades de la industria cinematográfica y la resistencia del público como alta empresa artística digna de las hazañas de una novela caballeresca. Con la obra cinematográfica de Rivette en mente cabría hacer, de hecho, una tentativa de distinción entre dos categorías difíciles de definir a priori, pero constatables en la filmografía de directores de marcada impronta autoral: de un lado de la pantalla, el cine quijotesco (el de Welles y Rivette y un cierto Truffaut quizá, sin olvidar a Terry Gilliam, antes y después de su imposible adaptación del Quijote) y, del otro, el cine cervantino (con Jean-Luc Godard, líder evidente de este estilo crítico-creativo de entender el cine, y algunos de sus seguidores más irónicos, como Raoul Ruiz desde los años setenta hasta bien entrado el siglo Xxi, como valedores fílmicos de la aventura estética iniciada por Cervantes). Gracias al cine, como apunta Sánchez, «El Quijote está, pues, salvado de la quema del tiempo: ese fuego que es supremo hacedor y quemador».

En suma, como muestran las reflexiones suscitadas por la lectura de todos estos textos, la inmortalidad estética de una obra no se mide solo por su lugar en las bibliotecas, públicas o privadas, o en las universidades, el número de especialistas que se ocupan de ella o el tipo de especulaciones que suscitan entre los estudiosos a lo largo del tiempo, sino por su capacidad efectiva para reclamar la recreación, la remediación y la reinvención. Por su poder absoluto para inspirar e inseminar a artistas y creadores de otros medios e incitarlos a crearla de nuevo en otros soportes artísticos o tecnológicos. Una y otra vez. $\mathrm{Al}$ infinito.

En el futuro, en cualquier caso, si todo sigue los derroteros previstos en el mundo del siglo xxI, cabe esperar que El Quijote disfrute ya de una segunda existencia tecnológica que habrá vuelto gratuitas y desfasadas estas observaciones propias de una era de transición cultural como la nuestra.

Pero esa es otra historia. 
TRANSLATING THE CLASSICS AND THE AGENCY OF THE TRANSLATOR

Peter Bush

Traductor

The contemporary translator of fiction is bound by conventions that do not necessarily trouble a theatre translator. The latter has to ensure that tickets are sold, that the production is financially viable, that audiences come, and so whole acts or characters can be erased, though these decisions may also be made by a director, or the writer who is often employed by the theatre company to work on the translation produced by someone who actually knows the original language. Whatever their place in this peculiar hierarchy in the English theatre, theatre translators know they are part of some kind of collaboration. The translator of fiction, however, is generally expected to translate what is on the pages of the original text: "fidelity" is the implied norm that is usually categorised in the translator's contract as an instruction to be "faithful to the original in good literary English". Large-scale changes are unusual and decisions to axe chapters will be taken by editors after they have read the translation -English publishers/editors tend not to read any foreign languages - though they may contract the translator to do any extensive edit and would seek the permission of the writer. Writers are keen to appear in English, and tend to acquiesce readily to such requests for cuts. For example, when I sent my translation of Miguel Sousa Tavares's Ecuador to Bloomsbury (2009), the publisher, Liz Calder, thought that the opening fifty pages set in Lisbon and giving the historical context to the novel were too lengthy and over-delayed the real action, so they were cut with the author's reluctant agreement.
Calder was also of the opinion that the various sex scenes were too clichéd and asked me to sharpen up the language, so the "steam" was less routine. Similarly, when Farrar Straus Giroux published Sánchez Piñol's Cold Skin in Cheryl Leah Morgan's translation (2005), they axed all references to the IRA, which they deemed to be unnecessary. Canongate in Edinburgh had included them in their edition earlier in that same year.

When it comes to the classics, the same conventions obtain in terms of translations for print publication, even though the writers may be dead and have long been out of copyright. Indeed, the weight of tradition and academic scholarship tend to reinforce the pressure on the translator to conform, and be reverential, especially in choice of lexis and narrative movement. Academic scholars exert another pressure inasmuch as they will often be asked to review translations of classics that fall within their foreign literary field. When my translation of Juan Carlos Onetti's modern classic, El pozo, was published by Quartet Books (I99I) as The Pit, Latin Americanist Jason Wilson criticised my choice of title in a review in the Times Literary Supplement, asserting that it should have been The Well, and that the French translator was correct to use Le Puits. I had in fact discounted that possibility as being too bucolic for Onetti's grim tale of urban despair.

However, in the English-speaking world most translations, whether of classics or contemporary fiction, tend to be single editions, one-offs, with the exception of a small number of super classics by Cervantes, Dante, Flaubert, Tolstoy and other "household' names who are constantly re-translated and re-published alongside a growing number of noir authors, all of which benefit from film and television series versions. The first three super canonical authors' 
most re-translated works are Don Quixote, The Inferno and Madame Bovary, which are guaranteed long reviews in the broadsheets and literary reviews. On the one hand, there must clearly be a market of readers who like to re-visit their favourite classics, and, on the other, critics are obviously fond of being given familiar foreign masterpieces to review. The phenomenon could equally be described as an exercise in intellectual inertia and a lack of a spirit of adventure in the realms of literary imagination.

There are also those classics that are re-translated less frequently, enjoy a brief presence on Anglo-Saxon horizons before vanishing out of sight once again. I would like to look at one case of a work that I have translated in order to underline the different levels of agency of the translator and the inevitable re-writing and re-interpretation that exists whatever any contractual clause says about "fidelity to the original". When I left the British Centre for Literary Translation in 2003 and went to live in Barcelona to resume life as a full-time literary translator, I decided that I wanted to translate more classics as well as modern fiction. One work high on my list was La Celestina. I took the idea to Eric Lane at Dedalus Books, a small publishing house that specialises in European Classics. Eric accepted my proposal that came with a specific interpretation built-in -I wanted to shed the theatrical framework, and structure Fernando de Rojas's masterpiece on the page as an embryonic novel. I was rather tired of the sequence of translations for the stage that always involved leaving out over half the work, and felt it was time for translation that firmly placed it in the European tradition of the novel. At the level of language I also told Eric that I wanted to avoid the attempts at archaic English present in most of those efforts for the theatre and create an English that would sound fresh and original as English - if de Rojas was creating a new literary Spanish for his time, there didn't seem much point in adding to the pseudo-Shakespearian English of my predecessors. to read James Mabbe's translation (I63I), that's the real thing! At the level of characterisation and themes, I also wanted to bring out the originality of the protagonist as a septuagenarian with sexual desire and the intensity of social class conflict in a small Castilian city at the end of the fifteenth century. My publisher was enthusiastic on all fronts and I set to work. When the book came out (2009), it received no reviews whatsoever. ${ }^{\mathrm{I}}$

In the meantime I sent the translation to John Siciliano, the editor of Penguin Classics in the United States, who immediately bought the us rights, even though I had informed him that Margaret Sayers Peden was preparing a translation for Yale up. I had talked about our different projects with Margaret at an ALTA conference, and knew that she intended to create a language that was full of archaic English. Celestina's American publisher believed this was all to the good and would stimulate critical interest: reviewers would be faced by two radically different interpretations. Well, it didn't, yet again no newspaper reviews, though both translations were reviewed for an academic journal specialising in medieval scholarship and Joseph Snow's verdict was that my translation was lively but unreliable and Sayers Peden's was more faithful. ${ }^{2}$ In any case, the experience demonstrated

I Peter Bush, 'The Centrality of a Translator's Culture: Fernando de Rojas's Celestina and the Creation of Style in Translation', The AALITRA Review: A Journal of Literary Translation, No.2 (Melbourne: Monash University, 2009), 2I-36.

2 Review of translations of La Celestina, by J. T. Snow, La corónica, A Journal of Medieval Hispanic Languages, Literatures and Cultures, 327-331. 
yet again that at the level of general readerships and mainstream press reviewers there was no burning desire to go beyond Don Quixote as the single representative of classical Spanish fiction in the European canon.

Nevertheless, the contributions by Eli Cohen and Ilan Stavans in the present volume reveal respectively how our knowledge of past translations of Don Quixote have been severely skewed by an over-reverence that poured scorn on John Phillips's 1687 translation and how translation into new languages within the English-speaking world like Spanglish can open up opportunities for new readerships to gain access to the novel. Both writers are academics interested in bringing a more subversive gaze to a canonical text that has more usually been sanitised as simply a "fun-book" by scholars opposed to more historical or ideological readings.

Eli Cohen details the uniformly hostile reception of John Phillips's translation: "hateful filthiness of the most foul production" (Diffield, I88I); a "travesty" (Ormsby, I887); "a disgraceful performance” (Putnam, I949). His historical analysis of Phillip's bold re-writing of Don Quixote shows how he was keen to speak to his contemporaries for political reasons, creating an "English according to the Humour of our Modern Language", that suggests an ironic commentary on the licentiousness and libertinism of the court of Charles II, or for some, "anti-Catholic satire" by this nephew of John Milton. The action is transferred to London taverns and streets and the language revels in sexual innuendo and ribald remarks from the very start: of the Don's steed - "The horse that eats no Oats, no Oats can shite", and of his family - "the Niece of Twenty for private recreation". A number of Cervantine scholars like Eli Cohen and Jonathan Thacker are drawing attention to Phillips in the light of the new

theoretical interest in the agency of the literary translator and translation as writing that is both re-creation and original. One eagerly awaits a modern edition of Phillips's translation, an event that would crown his writerly achievements and de-sanctify centuries of staid "fidelity" by translators over-awed by an original that is, in fact, constantly being jocular towards the act of translation.

Ilan Stavans is a university professor who has written scholarly books and articles on the subject of Don Quixote, but he is also an atypical academic Hispanist who sees scholarship as "an act of rebellion" and has a desire to reach the general public, and in the context of Cervantes, to bring his masterpiece "to a community of readers prone to other types of entertainment". Such projects call for "a creative edge" in re-creations of the novel in Spanglish, a hybrid, non-standard form of English used by millions of citizens of the United States. Here we publish excerpts from two of Stavan's recent Spanglish adaptations: one is prose fiction; the other is in the form of a cartoon comic drawn by Roberto Weil, accompanied by bubbles with Stavans's Spanglish. In the present political context in the USA these adaptations can be seen as hugely subversive in that they legitimise and give literary form to a language used by millions who find themselves under attack from a xenophobic president, and a media culture where non-standard forms of language are constantly ridiculed and caricatured, and demonised by "reality" television shows. Like Phillips's translation, they also challenge conventional adherence to "fidelity" in translation, and academic pedantry that seeks to ring-fence Don Quixote for an elite, a novel whose myriad stories have been plundered for centuries by popular entertainers and are now recreated across the new technologies for entertainment as discussed 
elsewhere in this volume. Unlike the weighty tomes of annotated anniversary editions produced by cohorts of humourless dons, Stavans's Spanglish versions sparkle with humour and intelligence and reach out to readers who might otherwise have considered Cervantes to be beyond them.

The focus that both Cohen and Stavans bring to the conscious re-writing of translators indirectly lends support to my interpretation of the Borges story about Pierre Ménard that has been turned into a speculative parable on the nature of translation by scholars like George Steiner. ${ }^{3}$ The French man is clearly not translating, but copying out the original text, and though this could trigger different mental states at the time of his various bouts of copying, they are mental states far removed from an act of re-writing. The act of translating the story into English immediately confronts the translator with the task of translating the quotation from Cervantes's text. Does he or she use an existing translation, leave the quotation in Spanish, or make a new translation that chimes with the overall strategy of the translation? Leaving it in Spanish would obfuscate for the reader the key nature of the quotation Borges chose. Translating it into whatever version would demonstrate the palpable opposition between serial copying and a translator's re-writing. It would also point up the agency of translators as exemplified by the creative process of decision-making and honing of style through acts of translation that lead to different arrays of letters on the page driven by a range of critical insights and writerly moves.

To underline the continued literary conservatism that lingers on in the tradition of Don

\footnotetext{
3 Peter Bush, "Intertextuality and the Translator as Story-teller", Palimpsestes, i8, (Presses Sorbonne Nouvelle) I5 June 2006, 213-229.
}

Quixote translations and remains opposed to the scurrilous spirit of seventeenth-century Phillips or the subversive language choice of twenty-first-century Stavans, I would like to comment on a fragment from Don Quixote and Sancho Panza's visit to Barcelona towards the end of Part II as translated by John Ormsby, Edith Grossman and John Rutherford. The men from La Mancha are taken to the harbour by their host Don Antonio Moreno and are invited on board a ship, the captain of which is delighted to have the opportunity to meet these characters who had so famously featured in Part One of the novel:

pasóse el cómitre en crujía y dio señal con el pito que la chusma fuera ropa, que se hizo en un instante. Sancho, que vio tanta gente en cueros, quedó pasmado...

the boatswain passed along the gangway and piped all hands to strip, which they did in an instant. Sancho, seeing such a number of men stripped to the skin, was taken aback...

(John Ormsby, 1885)

the boatswain walked in to the midship gangway and piped the order to strip, which was done in an instant. Sancho was astonished to see so many half-naked men...

(John Rutherford, 2000)

the boatswain passed along the midship gangway and signalled on his whistle for the oarsmen to strip to the waist, which they did instantly. Sancho was stunned to see so many people undressed...

\section{(Edith Grossman, 2003)}

The reader imagines that Sancho has had little previous experience of the sea and that this being the first time that he has been aboard a galley driven by galley-slaves, he is astonished 
by the dramatic sight of so many men being ordered to strip stark naked. There is little to choose between these fragments, though in the paragraphs from which they are taken, only John Rutherford uses the word "galley-slaves", but not in this particular couple of sentences. Ormsby uses "crew" or "men" or "hands", perhaps his decorous Victorian sensibility was averse to the mention of slaves? Edith Grossman's choices reveal an even more strenuous desire for an inoffensive translation, in line with the contemporary requirement of political correctness. She constantly uses "oarsmen". On the other hand, Ormsby does have "the men stripped to the skin" whereas Rutherford has them "strip" and then "half-naked" and Grossman has "stripped to the waist" and then "undressed", and explains in a footnote that this is so they are ready to start rowing. The order piped was for the slaves to take off their clothes, which instantly left them stark naked, and it is this sudden spectacle of stark nakedness that shocks Sancho. There is a remarkable sameness about the three translations in their lack of dramatic physicality in terms of Sancho's reactions,

and the actual scene of rags being cast off and naked flesh exposed. This, in turn, softens the impact later in the paragraph when Sancho is picked up and tossed round the boat by the slaves.

In conclusion, the agency of literary translators of prose fiction, even of much translated canonical works like Don Quixote, continues to be restricted by a publishing culture that expects a "fidelity" that leans towards conventional literary style and a tone that is neither jagged nor jarring, mellowing detail that might shock. The agency of some translators, as described here, involves an acceptance of this culture. Eli Cohen's account of Phillips's subversive Cervantes and Ilan Stavans's Spanglished Cervantes show the potential for radically innovative translations that open up the text to other readerships. Perhaps it is time for a translator to attempt a re-writing of Don Quixote that is disturbing, doesn't shy away from underlying themes of social and political conflict and retains the violence and the comedy. Could any publisher be drawn to a more staccato, gritty narrative movement for Sancho and his master? 